\title{
ZRÓŻNICOWANIE NARCYZMU I MAKIAWELIZMU U OSÓB UZDOLNIONYCH PLASTYCZNIE I OSÓB O UZDOLNIENIACH PRZECIĘTNYCH
}

\begin{abstract}
STRESZCZENIE
Narcyzm i makiawelizm to dwie z trzech składowych Ciemnej Triady Osobowości, opisanej po raz pierwszy przez Paulhusa i Williamsa. Konstrukt ten charakteryzuje się wysokim nasileniem pewnych cech, m.in. egoizmem i tendencją do manipulowania innymi ludźmi. Przeprowadzone badania miały na celu udzielenie odpowiedzi na pytanie, czy osoby uzdolnione plastycznie różnią się od osób o przeciętnych uzdolnieniach pod względem nasilenia cech narcystycznych i makiawelistycznych.

W badaniach wzięło udział 141 osób. Spośród nich 74 były studentami Akademii Sztuk Pięknych, 67 było studentami innych uczelni, niezwiązanych z dziedzinami artystycznymi. Badania przeprowadzono, wykorzystując Kwestionariusz Narcyzmu NPI Ruskina i Halla w polskiej adaptacji Bazińskiej i Drat-Ruszczak oraz skalę Mach IV Christiego i Geis, badającą postawę makiawelistyczną.

Uzyskane wyniki pokazują, iż uzdolnienia plastyczne są czynnikiem istotnie różnicującym poziom badanych cech. Osoby uzdolnione plastycznie charakteryzują się wyższym poziomem makiawelizmu oraz narcyzmu w pewnym zakresie w porównaniu do osób o uzdolnieniach przeciętnych. Ponadto wyniki pokazały, iż znaczenie ma nie tylko fakt posiadania uzdolnień, lecz także przekonanie o własnym artyzmie.
\end{abstract}

Słowa kluczowe: narcyzm, makiawelizm, uzdolnienia plastyczne

\section{DIFFERENTIATING NARCISSISM AND MACHIAVELLIANISM in PEOPLE ARTISTICALLY GIFTED AND WITH AVERAGE ARTISTIC SKILLS}

\section{Abstract}

Narcissism and machiavellianism are two out of three components of the Dark Triad proposed by Paulhus and Williams. This construct is characterized by high intensification of certain features for example egoism and manipulatory tendencies. The goal of this study was to find if people with artistic skills differ from those without any artistic skills in intensification of machiavellistic and narcissistic traits.

The study was undertaken on 141 adults from which 74 were students of The Academy of Fine Arts and 67 were students of other Universities not associated with art. Study

1 Adres do korespondencji: lopuszanska.julia@gmail.com. 
was conducted using Narcissistic Personality Inventory (NPI) by Ruskin and Hall in polish adaptation by Bazińska and Drat-Ruszczak and Mach IV Scale by Christie and Geis to analyze machiavelistic attitude.

Results indicate that art skills are factor that significantly differs level of evaluated traits. Subjects with artistic skills have higher level of machiavelistic and narcissistic traits in comparison to subjects without such skills. Furthermore results have shown that not only the fact of having art skills matters but also conviction of oneself artism.

Keywords: narcissism, machiavellianism, artistic skills

\section{WPROWADZENIE}

Narcyzm i makiawelizm stają się coraz bardziej znanymi pojęciami nie tylko w środowisku naukowym, lecz także w kulturze masowej. Mówi się wręcz o czasach panowania kultury narcyzmu jako o epidemii kapitalistycznego społeczeństwa (Czarna, 2008; Olchanowski, Sieradzan, 2011). Różne modele wychowawcze skłaniają do refleksji nad kształtowaniem się u ludzi pożądanych i niepożądanych cech osobowości, w tym skłonności narcystycznych i makiawelistycznych. Inspiracją do badań stała się obserwacja zachowań społecznych w różnych sytuacjach i środowiskach, a w szczególności u osób uzdolnionych plastycznie, które kształcą się profesjonalnie, studiując kierunki artystyczne.

Narcyzm i makiawelizm są częścią szerszej koncepcji, zwanej Ciemną Triadą Osobowości. Koncepcja ta została wprowadzona przez Paulhusa i Williamsa (2002) i obejmuje łącznie trzy cechy osobowości: makiawelizm, subkliniczny narcyzm oraz subkliniczną psychopatię. Konstrukty te utworzyły jeden czynnik, co przemawia za tym, że stanowią one jeden wymiar osobowości. Cechą wspólną poszczególnych konstruktów jest brak społecznej akceptacji dla nich, gdyż wszystkie trzy charakteryzuje tendencja do manipulowania innymi ludźmi, co wiąże się często z ich wykorzystaniem (Pilch, 2008a). Liczne badania (Nowak, Steuden, 2000; Popek, 2010; Poraj-Weder, Sekścińska, 2013) potwierdzają występowanie cech narcystycznych $u$ artystów, co jest przyczyną badania narcyzmu u osób uzdolnionych plastycznie. W badaniach tych potwierdza się istotną korelację między wymienionymi elementami Ciemnej Triady (Lee, Ashton, 2005; Jonason, Koenig, Tost, 2010; Furnham, Richards, Paulhus, 2013). Jest to jeden $\mathrm{z}$ powodów, dla których makiawelizm jest badany wraz z narcyzmem u osób uzdolnionych plastycznie.

\section{Pojęcie NARCYZMu}

Narcyzm jest zjawiskiem rozumianym i opisywanym przez naukowców na wiele sposobów, w zależności od paradygmatu. Początkiem naukowego zajmowania się narcyzmem było z całą pewnością opisanie go w świetle teorii psychoanalitycznych. Ojciec psychoanalizy, Freud, wystąpił jako pierwszy z teorią 
o jego znaczeniu na zebraniu Wiedeńskiego Towarzystwa Psychoanalitycznego w 1909 roku (Pospiszyl, 1995). Olchanowski i Sieradzan (2011), usiłując uporządkować zjawisko narcyzmu, wskazali, że może on oznaczać: w sensie genetycznym - etap w rozwoju życia człowieka, w sensie klinicznym - jednostkę chorobową, w kategoriach relacji społecznych - dominującą postawę charakteru. $\mathrm{W}$ niniejszej pracy najbardziej znaczące jest ujęcie narcyzmu w kategoriach cechy osobowościowej. Takie ujęcie prezentuje przejawianie przez osobę tendencji narcystycznych o względnie stałym charakterze, występujących w różnym nasileniu i ujawniających się w zachowaniu i myśleniu. Opisując narcyzm, można stwierdzić, że charakteryzuje się on pozytywnym obrazem własnej osoby przy jednoczesnym instrumentalnym stosunku do innych ludzi. Osoba narcystyczna przejawia trudności w nawiązywaniu $\mathrm{z}$ innymi relacji trwałych, opartych na zaufaniu, wsparciu i empatii. Inni ludzie stanowią dla niej swoiste „lustro”, dzięki któremu potwierdza ona pozytywny stosunek do siebie i daje możliwości podziwiania siebie. Osobę narcystyczną cechuje egocentryzm, który często czyni ją obojętną na dobro i prawa innych ludzi. Istotnym elementem w jej funkcjonowaniu jest tzw. narcystyczna złość, czyli intensywna wściekłość, która pojawia się w reakcji na niepożądane dla osoby sytuacje (Lowen, 1995; Bazińska, Drat-Ruszczak, 2000; Millon, Davis, 2005). Pierwsze wrażenie, jakie osoba o silnych tendencjach narcystycznych sprawia w kontaktach $z$ innymi, jest pozytywne, zazwyczaj jest otwarta i kontaktowa, potrafi przekonać do swoich racji. Jednak po pewnym czasie pozytywny obraz ulega negatywnej przemianie, co potwierdzają badania Paulhusa (1998). Wtedy mogą się ujawnić cechy arogancji, roszczeniowości, wymagań wobec innych, przeczulenia na własnym punkcie, zmienności, przypisywanie sobie sukcesów i obarczanie innych winą za porażki (Czarna, 2011).

Przedstawiając pojęcie narcyzmu, warto zwrócić uwagę na teorię Kohuta (1977, za: Gościniak, Mocek, 2008), który w przeciwieństwie do ojców koncepcji psychoanalitycznych spojrzał na zjawisko od innej strony. Pozbawił je pejoratywnego znaczenia, przypisując narcyzmowi zespół przyjemnych odczuć związanych z własną osobą. W swoim ujęciu Kohut zawarł potrzebę bycia podziwianym oraz przekonanie o byciu „centrum świata” (Bazińska, Drat-Ruszczak, 2000). Pozytywna strona narcyzmu to dojrzały szacunek i zaufanie do samego siebie. Osoby narcystyczne mogą być twórcze, cechuje je humor i mądrość oraz stabilne poczucie własnej wartości. Narcyzm jest siłą rozwojową, która według Kohuta może się wiązać także ze zmianami patologicznymi. Autor teorii widział w osobie narcystycznej człowieka tragicznego, miotanego przez wewnętrzne nakazy, które nigdy nie mogą się spełnić ani zostać zaspokojone. Osoba narcystyczna jest zraniona i unika bliskości, za którą tak naprawdę tęskni. Narcyzm może się rozwinąć w pierwszych latach życia dziecka, m.in. na skutek niezaspokajania ważnych potrzeb przez matkę lub idealizacji ojca przez brak kontaktu z nim (Pospiszyl, 1995; Gościniak, Mocek, 2008; Czarna, 2011). W zaprezentowany 
wyżej sposób widzi przyczyny narcyzmu Karen Horney (1994), według której tendencje narcystyczne mogą się ujawniać przez niekorzystne relacje z rodzicami, co skutkuje zaniżonym poczuciem własnej wartości.

Dokonując charakterystyki narcyzmu, warto wyjaśnić, czym jest narcystyczne zaburzenie osobowości. Według DSM V (2015) cechy diagnostyczne obejmują m.in. megalomańskie poczucie ważności, fantazjowanie o sukcesie i władzy, wymaganie nadmiernej admiracji, stosowanie wyzysku w kontaktach $\mathrm{z}$ innymi, brak empatii. Omawiane zaburzenie osobowości ujawnia się w różnych kontekstach, diagnozowane jest najczęściej po 18. roku życia. W kontekście niniejszych badań nie można mówić o diagnozie zaburzenia osobowości, lecz o tendencjach narcystycznych, które, w różnym nasileniu, przejawia każdy. To właśnie ujawnione tendencje narcystyczne mierzy Kwestionariusz NPI Ruskina i Halla użyty do badań i opisany w dalszej części pracy. Zatem wśród wymienionych w kwestionariuszu zachowań istotne są te, które charakteryzują się arogancją, ekstrawersją, postawą roszczeniową w kontaktach z innymi ludźmi.

\section{Pojęcie makiawelizmu}

Pojęcie makiawelizmu na grunt nauki zaadaptował Christie (1970), czerpiąc z bogactwa piśmiennictwa czasów odrodzenia. Źródłem omawianych konstelacji cech stało się dzieło Książę Machiavellego. W obecnym czasie, kiedy psychologia zajmuje się badaniem związków społecznych m.in. w korporacjach, na rynku pracy czy w polityce, pojęcie osobowości makiawelicznej staje się istotne (Pilch, 2006). W niniejszym artykule makiawelizm traktowany jest jako wymiar osobowości, czyli względnie stały zespół cech, charakteryzujący się przede wszystkim: brakiem przywiązania do powszechnie podzielanych norm moralnych, koncentracją na osiąganiu realistycznych zamierzeń, brakiem uczuć w kontaktach interpersonalnych, brakiem empatii, tendencją do manipulowania innymi, nastawieniem na kontrolowanie sytuacji zewnętrznej (Pilch, 2008a; Czerniawska, 2013). Ponadto makiawelizm cechuje dążenie do przewagi i osobistych korzyści, umiejętność strategicznego myślenia i planowania oraz kierowanie się bilansem zysków i strat (Pilch, 2014). Cechą osiową człowieka manipulującego jest emocjonalny chłód, który objawia się przez umiejętność kontrolowania przebiegu interakcji. Osoby o cechach makiawelicznych potrafią bardzo trafnie ująć i rozumieć intencje swoich rozmówców oraz przekonać do swojego zdania, co jest zbieżne z cechami narcystycznymi. Zarazem jednak charakteryzuje je brak zaangażowania emocjonalnego w daną sytuację oraz brak zainteresowania bliskością (Jaroszek, 2001). Wskazuje to, że makiaweliści, mimo braku empatii i przywiązania do ludzi, mają pewne umiejętności społeczne, dzięki którym mogą innych zwodzić i nimi manipulować, często bez żadnej świadomości osób zaangażowanych w relacje. Inni z kolei mogą być 
przez nich odbierani jako niegodni zaufania, cyniczni, podejrzliwi (Witkowski, 2005; Pilch, 2008a).

W literaturze przedmiotu charakterystykę osoby makiawelicznej udało się ujednolicić dzięki licznym badaniom empirycznym, które wykazują związki między omawianym konstruktem a innymi wymiarami osobowości i zachowania. Wiele z nich dotyczy korelacji makiawelizmu ze znanymi czynnikowymi koncepcjami osobowości. W odniesieniu do modelu Wielkiej Piątki makiawelizm negatywnie koreluje z Ugodowością. Łączy się to z przypisywaniem osobom o cechach makiawelicznych egoizmu, kłótliwości, niecierpliwości, nieufności (Jonason i in., 2010).

Drugim istotnym modelem wyjaśniającym opisywany konstrukt jest model sześcioczynnikowy HEXACO. Czynnik uczciwość-pokora koreluje ujemnie z całą Ciemną Triadą. Wyjaśnia to sposób realizacji celów przez makiawelistów, którzy potrafią ignorować obowiązujące normy (Lee, Ashton, 2005; Strus, Cieciuch, 2014). Wykazuje się też związki makiawelizmu z wysokim poziomem sprawczości oraz niskim poziomem wspólnotowości. Wskazuje to na przywiązanie do wartości sprawczych, m.in. władzy, sławy, bogactwa czy ambicji, kosztem wartości wspólnotowych, czyli uczciwości, altruizmu, współczucia (Pilch, 2014). Badania Pilch (2008b) na gruncie polskim wskazują na dodatni związek makiawelizmu z emocjami negatywnymi, neurotycznością i lękiem, a także na negatywną korelację z nadzieją i poczuciem szczęścia. Badania te ujawniają nieco inną stronę makiawelicznego świata, którego nie cechuje wyłącznie zimny osąd, brak emocji, dążenie do władzy i korzyści, ale również pewien syndrom cierpienia, podobnie jak w przypadku osób $\mathrm{z}$ wysokim poziomem narcyzmu (Lowen, 1995; Pospiszyl, 2000).

Warto podkreślić, że między narcyzmem i makiawelizmem zachodzi związek, który potwierdzają liczne badania (Paulhus, Williams, 2002; Lee, Ashton, 2005; Furnham i in., 2013), opisane szczegółowo w dalszej części pracy. Cechami wspólnymi omawianych konstruktów są m.in.: interpersonalny antagonizm, niski poziom empatii, skłonność do niezgadzania się (Furnham i in., 2013). Wspólne może być również manipulowanie innymi. Jednak osoby narcystyczne robią to $\mathrm{w}$ celu dowartościowania się, zwrócenia na siebie uwagi i podziwu, a osoby makiaweliczne - w celu zdobycia korzyści.

\section{UZdOLNIENIA PLASTYCZNE W KONTEKŚCIE NARCYZMU I MAKIAWELIZMU}

W odniesieniu do badanej grupy, jaką stanowią osoby uzdolnione plastycznie, należy zwrócić się ku zagadnieniu twórczości oraz specjalnych uzdolnień, które są szeroko opisywane w literaturze przedmiotu. Pojęcie twórczości odnosi się zarówno do osób, które są uzdolnione wszechstronnie, jak i do tych uzdolnionych w konkretnej dziedzinie. Tym samym można jednocześnie być bardzo twórczym w dziedzinie sztuki lub poezji, a wykazywać niski poziom 
twórczości w rozwiązywaniu konfliktów lub w relacjach interpersonalnych (Sękowski, 2004). Niektóre z opisywanych cech narcystycznych w sposób szczególny mogą dotyczyć osób uzdolnionych plastycznie, tworzących własne dzieła. Jako pierwszy na możliwe tendencje narcystyczne u artystów zwrócił uwagę Freud (1917, za: Nowak, Steuden, 2000). W swoich pracach pisze on o konotacjach narcyzmu z twórczością, a sam narcyzm traktuje jako czynnik inicjujący aktywność człowieka. Aktywność twórcza jest sublimacją na drodze do zaspokajania popędów, może jednak również stanowić przejaw chęci zdobycia laurów, sławy, zaszczytów, podziwu innych. Eksponując swoją twórczość, przez interakcję dzieła z odbiorcami twórca staje się bohaterem, artystą, ulubieńcem. Twórczość osób narcystycznych wiąże się ponadto ze sprawczością. Tym samym działania, które podejmują osoby narcystyczne, mogą być bardziej owocne, jeśli łączą się z konsekwencją zdobycia chwały i glorii odbiorców. Publiczność zdaje się wyzwalać w osobach narcystycznych to, co w nich najlepsze. Badania Wallace'a i Baumeistera (2002) pokazują, że osobom o cechach narcystycznych w dużej mierze zależy na stworzeniu i utrzymaniu dobrego wizerunku w oczach innych oraz własnych. Dlatego im trudniejsze jest zadanie, tym większa motywacja, aby mu sprostać i udowodnić swoją wartość. Goncalo, Flynn i Kim (2010) badali twórczość u osób narcystycznych. Według badaczy osoby takie uważają się za bardziej utalentowane, zdolne i twórcze od innych. Jednak w ocenie ekspertów ich prace nie są lepsze czy bardziej wybitne. Co ciekawe, dzięki bezpośredniej rozmowie osoby narcystyczne potrafią przekonać innych do swoich zdolności i talentu, przez co czasami mogą być postrzegane jako bardziej twórcze. Na narcyzm u twórców zwraca uwagę Kohut, który porównuje idealistyczną relację matki do dziecka z relacją twórcy i jego dzieła. Przyczyną może być ambicja osób twórczych, głód uznania, dążenie do perfekcji (Gościniak, Mocek, 2008). Na bezpośrednie powiązania twórców z narcyzmem zwraca uwagę Popek (2010), przy jednoczesnym wykazywaniu wielu zmienności i sprzeczności w zachowaniu. Spotykane mogą być u nich również zabiegi o wywarcie wrażenia na innych, perfekcjonizm lub brak odporności na krytykę (Poraj-Weder, Sekścińska, 2013).

Makiawelizm jest badany w niniejszej pracy ze względu na występujące korelacje z narcyzmem (Paulhus, Williams, 2002; Lee, Ashton, 2005). W literaturze przedmiotu nie znajdziemy bezpośrednich badań dotyczących związku makiawelizmu $\mathrm{z}$ uzdolnieniami plastycznymi, jednak na pewne powiązania w tym zakresie może wskazać charakterystyka osobowości twórców. Badania realizowane w tej tematyce pokazują, że twórcy dążą do osiągnięć, są otwarci na nowości, charakteryzuje ich ciekawość poznawcza i wykraczanie poza sztywne schematy. Są to osoby asertywne, dominujące, samowystarczalne, nieopierające się naciskom wewnętrznym i zewnętrznym, niezależne (Węgrzyn-Białogłowicz, 2009; Drozdowski i in., 2010). Możliwe są u nich zachowania wskazujące na brak zahamowań, nieskrępowanie konwenansami, niezależność od autorytetów 
(Trzebiński, 1980; Żuk, 1986; Stein, 1997; Popek, 1998). W rozważaniach nad osobami uzdolnionymi w kontekście cech makiawelistycznych warto wspomnieć o Kwestionariuszu EPQ-R Eysencka oraz jego skali Psychotyzmu, która z jednej strony określa skłonność do zachowań aspołecznych, z drugiej zaś wskazuje na cechy twórcze (Pospiszyl, 2000; Drozdowski i in., 2010).

\section{Problem I hipotezy}

Bazując na przedstawionych danych, postawiono następujące pytanie badawcze: Czy osoby uzdolnione plastycznie różnią się od osób o uzdolnieniach przeciętnych pod względem nasilenia cech narcystycznych i makiawelistycznych? Postawione pytania badawcze są punktem wyjścia do wysunięcia następujących hipotez:

H1: Osoby uzdolnione plastycznie charakteryzują się wyższym poziomem narcyzmu niż osoby o uzdolnieniach przeciętnych.

Popek (2010) zauważa, iż artyści plastycy mogą przejawiać w swojej życiowej postawie emocjonalne skrajności, np. egocentryzm, dominację czy narcyzm, przy jednoczesnej niskiej samoocenie. Zwraca również uwagę na silne skoncentrowanie na dziele przy jednoczesnym roztargnieniu i chaotyczności w innych dziedzinach. Argumentem za tym, że osoby uzdolnione plastycznie w większym stopniu przejawiają cechy narcystyczne, jest charakterystyka osobowości twórcy. Osoby twórcze i uzdolnione przejawiają w swojej postawie cechy, które $\mathrm{w}$ jakimś stopniu mogą być zbieżne $\mathrm{z}$ kryteriami nieklinicznego narcyzmu. W charakterystyce osób uzdolnionych obecne są: egocentryzm, niezależność, dominatywność, przejawianie skrajności w zachowaniu (Żuk, 1986; Popek, 2010; Drozdowski i in., 2010; Poraj-Weder, Sekścińska, 2013). Badania Goncalo i in. (2010) wskazują, iż osoby narcystyczne uważają się za bardziej kreatywne i utalentowane od innych, co może sugerować występowanie w większym nasileniu cech narcystycznych u osób studiujących na Akademii Sztuk Pięknych.

$\mathrm{H}$ 2: Osoby uzdolnione plastycznie charakteryzują się wyższym poziomem makiawelizmu niż osoby o uzdolnieniach przeciętnych.

W literaturze wskazuje się na powiązania narcyzmu z makiawelizmem. Paulhus i Williams (2002), twórcy Ciemnej Triady, wskazują na zależność wynoszącą $r=0,25$. Z kolei według Lee i Ashtona (2005) korelacja ta wynosi $r=0,17$. Autorzy zwracają jednocześnie uwagę na różnorodność metod służących do badania narcyzmu; w zależności od doboru korelacje wynoszą do $r=0,36$. Na powiązania między badanymi cechami zwraca również uwagę Pilch (2014), wskazując na korelacje do $r=0,6$. Kolejnym powodem badania makiawelizmu u twórców jest opisywana w literaturze ich osobowość, w której pewne cechy są zbieżne z cechami osobowości makiawelistycznej. Według starszych badań są to m.in.: skłonność do ryzyka, nonkonformizm, niezależność, brak potrzeby bliskich kontaktów z innymi ludźmi, nieuznawanie autorytetów (Trzebiński, 
1980; Żuk, 1986; Popek, 1998). Nowsze badania, m.in. Węgrzyn-Białogłowicz (2009), wskazują na tendencję osób uzdolnionych plastycznie do manipulowania innymi przez „wkradanie się" w łaski, czyli osiąganie założonych celów dla uzyskania korzystnej oceny społecznej. Według Drozdowskiego i in. (2010) osobowość twórcza silnie łączy się z niezależnością. Autorzy podkreślają rolę tej cechy w zaistnieniu procesu twórczego, jednocześnie wskazując na występowanie indywidualizmu i nonkonformizmu, kwestionowanie istniejących norm i wartości oraz wyznawanie niekonwencjonalnych poglądów.

\section{MetodA}

\section{Osoby badane i przebieg badań}

Badaną grupę I stanowią osoby tworzące własne dzieła, studenci Akademii Sztuk Pięknych i kierunków artystycznych (TYP_ART - 74 osoby). Grupę II stanowią osoby, które nie studiują na kierunkach artystycznych (TYP NIE_ART - 67 osób). Łącznie w badaniach uczestniczyło 141 osób w wieku 19-26 lat (111 kobiet i 30 mężczyzn) z Akademii Sztuk Pięknych w Krakowie oraz z Katolickiego Uniwersytetu Lubelskiego Jana Pawła II. O przydzieleniu do danej grupy decydowało kryterium psychopedagogiczne - udzielenie odpowiedzi twierdzących lub zaprzeczających w ankiecie dodanej do baterii metod badawczych. Pytania dotyczyły tego, czy dana osoba studiuje kierunek artystyczny, czy tworzy prace, czy jej dzieła są wystawiane na ekspozycję społeczną (ocenę większej grupy osób). Przeprowadzona ankieta pozwoliła na drugi, dodatkowy podział osób badanych, który jest istotny w prezentowaniu wyników oraz wniosków pracy. W związku z tym grupę III stanowią osoby, które uważają siebie za uzdolnione plastycznie i studiują kierunek artystyczny (PRZEKONANIE TYP_ART - 69 osób). Grupę IV stanowią osoby, które nie uważają siebie za uzdolnione plastycznie i nie studiują na ASP (PRZEKONANIE TYP NIE_ART - 58 osób). Prezentowany podział na cztery grupy pozwala na analizowanie danych zarówno ze względu na fakt studiowania kierunku artystycznego, jak i ze względu na przekonanie o własnym artyzmie.

\section{Narzędzia badawcze}

Pierwszym narzędziem badawczym jest polska adaptacja kwestionariusza NPI Raskina i Halla (1979), dokonana przez Drat-Ruszczak i Bazińską (2000), pozwalająca ocenić nasilenie narcyzmu wyrażonego w wyniku ogólnym oraz w czterech skalach kwestionariusza: Próżności (5 pozycji), Samowystarczalności (7 pozycji), Przywództwa (11 pozycji), Domagania się Podziwu (11 pozycji). Skala Przywództwa odnosi się do przekonania o własnych zdolnościach przywódczych oraz poglądu, że ma się wpływ na innych. Skala Domagania się Podziwu odzwierciedla potrzebę bycia zauważonym, potrzebę znaczenia, bycia podziwianym, komplementowanym i sławnym. Skala Próżności ma za zadanie 
odzwierciedlać miłość badanego do siebie, czyli można tu mówić o nawiązaniu do narcyzmu mitologicznego. Dotyczy to przede wszystkim własnego ciała i poczucia estetyzmu. Skala Samowystarczalności dotyczy przekonań o własnej niezależności, indywidualizmie, przekonań o własnym sukcesie i wysokiej kompetencji. Kwestionariusz składa się z 34 pozycji. Tłumaczenia dokonali z języka angielskiego w sposób niezależny psycholog oraz anglista. Badani odpowiadają na 5-stopniowej skali, która aktywizuje strukturę Ja, gdyż odnosi się do osoby badanej w pierwszej osobie liczy pojedynczej, co ma na celu ułatwienie identyfikacji: „to nie Ja” (1), „to raczej nie Ja” (2), „trudno powiedzieć” (3), „raczej Ja” (4), „to Ja” (5) (Bazińska, Drat-Ruszczak, 2000).

Drugim użytym do badań narzędziem jest skala Mach IV Christiego i Geis (1970, za: Pospiszyl, 2000). Nowsza wersja (Mach V) krytykowana jest w literaturze przedmiotu ze względu na jej dłuższą formę oraz niższą rzetelność w porównaniu ze skalą Mach IV, której a Cronbacha > 0,70 (Pospiszyl, 2000; Pilch, 2008a). Mach IV mierzy nasilenie postawy makiawelistycznej. Zawiera ona 20 twierdzeń, które zaczerpnięto z dzieł Machiavellego. Odnoszą się one do niemoralnych poglądów rozumianych w sposób tradycyjny, stosowania pochlebstw i oszustw. Stwierdzenia są punktowane na skali od 1 do 7 (7 - całkowita zgoda, 1 - całkowity brak zgody). Obliczany jest wynik ogólny, ponad połowa możliwych do osiągnięcia punktów wskazuje na wykazywanie postawy makiawelicznej.

\section{WYNIKI}

Uzyskane wyniki dotyczące grup I i II pokazują, iż ogólny poziom narcyzmu w grupie osób studiujących kierunki artystyczne (grupa I) wynosi $M=105,23$. Najwyższe wyniki w ramach czterech podskal grupa ta uzyskała $w$ podskali Przywództwa $(M=32,2)$, a najniższe w podskali Próżności $(M=15,62)$. Średnia makiawelizmu wynosi $M=73,81$. Osoby niestudiujące kierunków artystycznych (grupa II) w skali narcyzmu uzyskały natomiast średnią $M=101,09$. Najwyższe wyniki grupa ta, podobnie jak analizowana wyżej, uzyskała w podskali Przywództwa $(M=31,67)$, a najniższe w podskali Próżności $(M=14,31)$. Średnia makiawelizmu wynosi $M=65,40$. Na podstawie uzyskanych danych dokonano porównania międzygrupowego za pomocą testu $t$ dla prób niezależnych. Istotnie wyższym poziomem makiawelizmu $(M=73,81)$ oraz narcyzmu, ale tylko w skali Próżności $(M=15,68)$, cechują się osoby uzdolnione plastycznie, studiujące kierunki artystyczne na ASP. Nieistotne statystycznie okazały się różnice dotyczące ogólnego poziomu narcyzmu oraz narcyzmu w skali Podziwu, Samowystarczalności i Przywództwa. 
Tabela 1

Średnie (M), odchylenie standardowe (SD), test $\mathrm{t}$, poziom istotności (p) skali Narcyzmu (wynik ogólny i 4 podskale) i Makiawelizmu (wynik ogólny) w grupach I i II (TYP_ ART oraz TYP NIE_ART)

\begin{tabular}{lcccccc}
\hline \multirow{2}{*}{ Skala } & \multicolumn{2}{c}{ TYP_ART } & \multicolumn{2}{c}{ TYP NIE_ART } & \multicolumn{2}{c}{$\begin{array}{c}\text { Test } t \text { dla prób } \\
\text { niezależnych }\end{array}$} \\
\cline { 2 - 8 } & $M$ & $S D$ & $M$ & $S D$ & $t$ & $p \leq$ \\
\hline Suma NPI & 105,23 & 19,08 & 101,09 & 20,87 & 1,23 & 0,11 \\
\hline Podziw & 32,08 & 7,84 & 30,31 & 8,73 & 1,26 & 0,104 \\
\hline Próżność & 15,68 & 4,31 & 14,31 & 4,47 & 1,81 & 0,035 \\
\hline Samowystarczalność & 25,25 & 4,04 & 24,76 & 3,72 & 0,75 & 0,225 \\
\hline Przywództwo & 32,20 & 7,80 & 31,67 & 7,69 & 0,40 & 0,344 \\
\hline Suma MACH IV & 73,81 & 14,22 & 65,40 & 13,81 & 3,55 & 0,001 \\
\hline
\end{tabular}

Uzyskane wyniki dotyczące grup III i IV pokazują natomiast, iż ogólny poziom narcyzmu w grupie osób przekonanych o własnym artyzmie (grupa III) wynosi $M=105,28$. Najwyższe wyniki w ramach czterech podskal grupa ta uzyskała w podskali Podziwu $(M=32,27)$, a najniższe w podskali Próżności $(M=15,88)$. Średnia makiawelizmu wynosi $M=73,53$. Osoby uważające się za nieuzdolnione plastycznie (grupa IV) w skali narcyzmu uzyskały natomiast średnią $M=99,08$. Najwyższe wyniki grupa ta uzyskała w podskali Podziwu i Przywództwa $(M=29,37)$, a najniższe w podskali Próżności $(M=13,84)$. Średnia makiawelizmu w tej grupie wynosi $M=65,74$. Na podstawie uzyskanych danych dokonano porównania międzygrupowego za pomocą testu $t$ dla prób niezależnych, podobnie jak w przypadku porównania grup I i II. Istotnie wyższym poziomem makiawelizmu $(M=73,81)$ oraz narcyzmu $(M=105,28)$ cechują się osoby przekonane o własnych uzdolnieniach. Również istotne statystycznie okazały się różnice poziomu narcyzmu w skali Podziwu i Próżności.

Tabela 2

Średnie (M), odchylenie standardowe (SD), test $\mathrm{t}$, poziom istotności (p) skali Narcyzmu (wynik ogólny i 4 podskale) i Makiawelizmu (wynik ogólny) w grupach III i IV (PRZEKONANIE TYP_ART oraz PRZEKONANIE TYP NIE_ART)

\begin{tabular}{lcccccc}
\hline \multirow{2}{*}{ Skala } & \multicolumn{2}{c}{$\begin{array}{c}\text { PRZEKONANIE } \\
\text { TYP_ART }\end{array}$} & \multicolumn{2}{c}{$\begin{array}{c}\text { PRZEKONANIE } \\
\text { TYP NIE_ART }\end{array}$} & \multicolumn{2}{c}{$\begin{array}{c}\text { Test } t \text { dla prób } \\
\text { niezależnych }\end{array}$} \\
\cline { 2 - 8 } & $M$ & $S D$ & $M$ & $S D$ & $t$ & $p \leq$ \\
\hline Suma NPI & 105,28 & 18,89 & 99,08 & 21,2 & 1,74 & 0,045 \\
\hline Podziw & 32,27 & 7,91 & 29,37 & 8,79 & 1,95 & 0,02 \\
\hline Próżność & 15,88 & 4,22 & 13,84 & 4,51 & 2,62 & 0,005 \\
\hline
\end{tabular}

Ciąg dalszy tabeli na następnej stronie 
Ciąg dalszy tabeli z poprzedniej strony

\begin{tabular}{lcccccc}
\hline \multirow{2}{*}{ Skala } & \multicolumn{2}{c}{$\begin{array}{c}\text { PRZEKONANIE } \\
\text { TYP_ART }\end{array}$} & \multicolumn{2}{c}{$\begin{array}{c}\text { PRZEKONANIE } \\
\text { TYP NIE_ART }\end{array}$} & \multicolumn{2}{c}{$\begin{array}{c}\text { Test } t \text { dla prób } \\
\text { niezależnych }\end{array}$} \\
\cline { 2 - 8 } & $M$ & $S D$ & $M$ & $S D$ & $t$ & $p \leq$ \\
\hline Samowystarczalność & 25,18 & 4,01 & 24,60 & 3,68 & 0,84 & 0,199 \\
\hline Przywództwo & 31,94 & 7,65 & 29,37 & 7,89 & 0,49 & 0,311 \\
\hline Suma MACH IV & 73,53 & 13,90 & 65,74 & 13,74 & 3,16 & 0,001 \\
\hline
\end{tabular}

\section{DyskusJa WYNIKów}

Prezentowane wyniki pokazują, że osoby studiujące na ASP istotnie różnią się od osób niestudiujących kierunków artystycznych tylko w jednym wymiarze tendencji narcystycznych: Próżności. Zatem hipoteza zakładająca, iż osoby studiujące na ASP charakteryzują się wyższym poziomem narcyzmu w porównaniu do osób o przeciętnych uzdolnieniach potwierdziła się w niewielkim stopniu. Wyższe wyniki w skali Próżności mogą świadczyć o miłości do siebie oraz do rozbudowanego poczucia estetyzmu (Bazińska, Drat-Ruszczak, 2000). Uzyskane wyniki pozostają częściowo w zgodzie z licznymi badaniami artystów, w tym osób uzdolnionych plastycznie, które wskazują na tendencje narcystyczne o różnym nasileniu (Freud, 1917, za: Nowak, Steuden, 2000; Popek, 2010; Poraj-Weder, Sekścińska, 2013). Cechy narcystyczne w wymiarze próżności mogą nawiązywać do faktu tworzenia przez artystów swoich autorskich prac, które są wyrazem ich samych, potrzebują zatem bycia docenionym przede wszystkim przez siebie samego, ale również przez innych. Fakt bycia zauważonym, publiczność, mogą być istotnym elementem lepszego samopoczucia, co potwierdzają badania Wallace’a i Baumeistera (2002). Wyższe wyniki w skali Próżności mogą świadczyć o tym, że osoby przekonane o swoich uzdolnieniach, tworzące autorskie prace, mają powód, by stawiać siebie na lepszej pozycji, gdyż potrafią robić coś, czego większość osób w populacji nie potrafi, a co budzi społeczny zachwyt i zadowolenie. Jest to wyrazem miłości i aprobaty dla siebie (Pospiszyl, 2000). Interpretując uzyskane dane dotyczące narcyzmu, należy zwrócić uwagę na drugi, dodatkowy podział osób badanych. Wyniki pokazały, iż w wyniku ogólnym oraz w skali Próżności i Podziwu osoby przekonane o swoim artyzmie charakteryzują się wyższym poziomem narcyzmu w porównaniu do grupy uważających siebie za nieuzdolnionych. Wyniki mogą sugerować, że większy wpływ na poziom narcyzmu ma fakt opinii na temat swoich uzdolnień, a nie obiektywne kryterium studiowania na kierunku artystycznym. Uzyskane dane dotyczące poziomu narcyzmu u osób przekonanych o swoim talencie pozostają w zgodzie z badaniami Goncalo i in. (2010), potwierdzającymi, iż osoby narcystyczne uważają siebie za bardziej kreatywne i twórcze, bez względu na faktyczny poziom zdolności. Ponadto wyższy poziom narcyzmu w skali Podziwu 
u osób uważających siebie za uzdolnione plastycznie może świadczyć o większej potrzebie bycia zauważonym, podziwianym, komplementowanym i sławnym w porównaniu do osób nieuważających siebie za utalentowane (Bazińska, Drat-Ruszczak, 2000). Z pewnością inne kryteria podziału grup, takie jak regularne wystawianie własnych prac na ekspozycję społeczną czy doświadczenie w zakresie pracy artystycznej, mogą w sposób istotny różnicować poziom narcyzmu u osób uzdolnionych plastycznie w stosunku do osób o przeciętnych uzdolnieniach. Jest to ciekawy aspekt przyszłych badań dotyczących przejawiania tendencji narcystycznych przez twórców.

Wyniki pokazały, iż osoby uzdolnione artystycznie istotnie różnią się od osób o przeciętnych uzdolnieniach pod względem przejawianych tendencji makiawelistycznych. Tym samym hipoteza zakładająca, iż osoby uzdolnione plastycznie charakteryzują się wyższym poziomem makiawelizmu, potwierdziła się w całości. Artyści mogą przejawiać większą tendencję do nieprzywiązywania się do powszechnie podzielanych norm moralnych, koncentrują się na osiąganiu realistycznych zamierzeń oraz na sobie. Ponadto mogą mieć większą zdolność do manipulowania, obojętności w kontaktach interpersonalnych czy braku empatii oraz silniejsze nastawienie na kontrolowanie sytuacji zewnętrznej (Pilch; 2008a, Siwy-Hudowska, Kieszkowska-Grudny, 2010). Uzyskane dane pokazały również, iż osoby przekonane o własnych uzdolnieniach cechują się wyższym poziomem makiawelizmu w porównaniu do osób nieuważających się za uzdolnione plastycznie. Mogą tym samym być bardziej nastawione na wartości sprawcze, zakładające realizację celów i planów, dążenie do sławy, przewagę (Pilch, 2014). Takie postrzeganie świata może sugerować, iż osoby przekonane o własnych uzdolnieniach są szczególnie nastawione na cel, na osiągnięcie zawodowego, a jednocześnie osobistego sukcesu. Mogą w większym stopniu charakteryzować się ambicją, dążeniem do własnych wystaw, rywalizować między sobą. W świetle prezentowanych wyników potwierdza się, iż niektóre z cech makiawelistycznych mogą być zbieżne z cechami przypisywanymi artystom. Są to m.in.: niezależność, indywidualizm przydatny w procesie twórczym, nonkonformizm, nieprzywiązywanie wagi do powszechnie obowiązujących norm i wartości (Drozdowski i in., 2010). Może to być również brak potrzeby bliskich kontaktów z innymi ludźmi, nieuznawanie autorytetów, samowystarczalność (Popek, 1998; Pospiszyl, 2000).

Uzyskane wyniki dają odpowiedź na pewne pytania i pokazują różnice międzygrupowe. Jednocześnie są inspiracją do stawiania wielu kolejnych pytań dotyczących m.in. przyczyn widocznych różnic, badań specyficznych grup, osobowości twórców. Wyniki badań pokazują, że warto zgłębiać prezentowane zjawiska, warto badać zależności między zmiennymi osobowościowymi a specyficzną grupą, jaką stanowią artyści, twórcy, osoby uzdolnione plastycznie. Ciekawym aspektem, który warto ująć w kolejnych badaniach dotyczących narcyzmu i makiawelizmu, są także różnice międzypłciowe, wskazywane przez 
wielu badaczy (Pilch, 2008a; Siwy-Hudowska, Kieszkowska-Grudny, 2010), oraz związek narcyzmu z makiawelizmem w różnych grupach badanych.

\section{Bibliografia}

Bazińska, R., Drat-Ruszczak, K. (2000). Struktura narcyzmu w polskiej adaptacji kwestionariusza NPI Raskina i Halla. Czasopismo Psychologiczne, t. 6, 3-4, 171-188.

Christie, R., Geis, F. L. (1970). Studies in machiavellianism. New York: Academic Press.

Czarna, A. (2008). Narcyzm - z perspektywy 120 lat istnienia pojęcia. W: P. Winiecki, R. Grzybek (red), Wybrane problemy współczesnej psychologii (s. 95-117). Wrocław: ATUT.

Czarna, A. (2011). Narcyz w sieci społecznej, czyli co analiza sieci mówi o funkcjonowaniu osób narcystycznych. Psychologia Społeczna, t. 6, 2(17), 130-146.

Czerniawska, M. (2013). Postawy wobec kultury i tradycji narodowej i ich osobowościowe uwarunkowania. Pogranicze. Studia Społeczne, t. XXI, 171-182.

Davis, R., Millon, T. (2005). Zaburzenia osobowości we współczesnym świecie. Warszawa: Instytut Psychologii Zdrowia PTP.

Drozdowski, R., Zakrzewska, A., Puchalska, K., Morchat, M., Mroczkowska, D. (2010). Wspieranie postaw proinnowacyjnych przez wzmacnianie kreatywności jednostki. Warszawa: Polska Agencja Rozwoju Przedsiębiorczości.

DSM-V (2015). Kryteria diagnostyczne $z$ DSM-V. Wrocław: Edra Urban \& Partner. Furnham, A., Richards, S., Paulhus, D. L. (2013). The Dark Triad of Personality: A 10 Year Review. Social and Personality Psychology Compass, 7(3), 199-216. Goncalo, J., Flynn, F., Kim, S. (2010). Are two narcissists better than one? The link between narcissism, perceived creativity, and creative performance. Personality and Social Psychology Bulletin, 36, 1484-1495.

Gościniak, J., Mocek, M. (2008). Narcyzm i patologia narcystyczna w ujęciu psychologii self Heinza Kohuta. Roczniki Psychologiczne, 2, 7-26.

Horney, K. (1994). Nasze wewnętrzne konflikty: konstruktywna teoria nerwic. Poznań: Rebis.

Jaroszek, J. (2001). Kiedy inteligencja społeczna nie przybliża do ludzi. Zjawisko makiawelizmu. Nowiny Psychologiczne, 2, 63-80.

Jonason, P. K., Koenig, B. L., Tost, J. (2010). Living a Fast Live. The Dark Triad and Life History Theory. Human Nature, 21, 428-442.

Lee, K., Ashton, M. C. (2005). Psychopathy, Machiavellianism, and Narcissism in the Five Factor Model and the HEXACO Model of Personality Structure. Personality and Individual Differences, 38, 1571-1582.

Lowen, A. (1995). Narcyzm: zaprzeczenie prawdziwemu Ja. Warszawa: Agencja Wydawnicza Jacek Santorski \& Co. 
Nowak, P., Steuden, S. (2000). Narcyzm jako czynnik modyfikujący twórcze aspekty osobowości. Czasopismo Psychologiczne, t. 6, 1-2, 19-24.

Olchanowski, T., Sieradzan, J. (2011). Wprowadzenie do problematyki narcyzmu. Od klasycznych koncepcji narcyzmu do narcyzmu kultury zachodniej. W: J. Sieradzan (red.), Narcyzm. Jednostka-społeczeństwo-kultura (s. 7-72). Białystok: Wydawnictwo Uniwersytetu w Białymstoku.

Paulhus, D. L. (1998). Interpersonal and intrapsychic adaptiveness of trait self-enhancement: A mixed blessing? Journal of Personality and Social Psychology, 74, 1197-1208.

Paulhus, D. L., Williams, K. (2002). The Dark Triad of personality: Narcissism, Machiavellianism, and psychopathy. Journal of Research in Personality, 36, 556-563.

Pilch, I. (2006). Osobowość makiawelisty i niemakiawelisty w ocenie własnej i partnerów. Czasopismo Psychologiczne, t. 12, 2, 265-273.

Pilch, I. (2008a). Osobowość makiawelisty i jego relacje z ludźmi. Katowice: Wydawnictwo Uniwersytetu Śląskiego.

Pilch, I. (2008b). Emocje i osobowość makiawelisty. W: A. Błachnio, A. Przepiórka (red.), Bliżej emocji II (s. 99-110). Lublin: Wydawnictwo KUL.

Pilch, I. (2014). Makiawelizm, narcyzm, psychopatia: ciemna triada jako próba opisania osobowości eksploatatora. Chowanna, 2, 165-181.

Popek, R. (1998). Z badań nad uzdolnieniami plastycznymi młodzieży. Analiza psychologiczna. Lublin: Wydawnictwo UMCS.

Popek, S. (2010). Psychologia twórczości plastycznej. Kraków: Oficyna Wydawnicza "Impuls".

Poraj-Weder, M., Sekścińska, K. (2013). Ile narcyza jest w artyście? Poziom narcyzmu u studentów Akademii Muzycznej w Łodzi i studentów Uniwersytetu Warszawskiego i Łódzkiego. W: E. Kumik, G. Poraj (red.), Konteksty kształcenia muzycznego. Prace teoretyczne i badawcze (s. 307-320). Łódź: Wydawnictwo Akademii Muzycznej w Łodzi im. Grażyny i Kiejstuta Bacewiczów.

Pospiszyl, K. (1995). Narcyzm. Drogi i bezdroża miłości własnej. Warszawa: WSiP. Pospiszyl, K. (2000). Psychopatia. Warszawa: Wydawnictwo Akademickie „Żak”. Sękowski, A. E. (red.), (2004). Psychologia zdolności. Współczesne kierunki badań. Warszawa: Wydawnictwo Naukowe PWN.

Siwy-Hudowska, A., Kieszkowska-Grudny, A. (2010). Osobowość makiaweliczna i jej czynniki w porównaniach międzypłciowych: znaczenie inteligencji emocjonalnej i lęku. Psychologia Społeczna, 5, 27-41.

Stein, M. I. (1997). Twórczość pod lupą. Kraków: Oficyna Wydawnicza „Impuls”. Strus, W., Cieciuch, J. (2014). Poza Wielką Piątkę - przegląd nowych modeli struktury osobowości. Polskie Forum Psychologiczne, 19(1), 17-49.

Trzebiński, J. (1980). Osobowościowe warunki twórczości. W: J. Reykowski (red.), Osobowość a społeczne zachowanie się ludzi (s. 105-131). Warszawa: Wydawnictwo „Książka i Wiedza”. 
Wallace, H. M., Baumeister, R. F. (2002). The performance of narcissists rises and falls with perceived opportunity for glory. Journal of Personality and Social Psychology, 82, 819-834.

Węgrzyn-Białogłowicz, K. (2006). Postawa twórcza a styl funkcjonowania interpersonalnego. W: W. Limont, K. Nielek-Zawadzka (red.), Dylematy edukacji artystycznej, edukacja artystyczna a potencjał twórczy człowieka, t. 2 (s. 237-258). Kraków: Oficyna Wydawnicza „Impuls”.

Witkowski, T. (2005). Inteligencja makiawelistyczna. Poznań: Moderator.

Żuk, T. (1986). Uzdolnienia twórcze a osobowość. Poznań: Wydawnictwo Naukowe Uniwersytetu im. Adama Mickiewicza w Poznaniu. 